\title{
A PIONEERING INSTITUTION FOR OMBUDSMAN: HISBAH
}

\author{
Ombudsmanlık İ̧in Öncü Bir Kurum: Hisbe
}

Prof. Dr. Hamza ATEŞ*

Geliş Tarihi: 09.07.2017 Yayına Kabul Tarihi: 10.08.2017

\section{Öz}

Hisbe kelimesi literatürde "hesaplamak" ya da "mükâfatlandırmak" anlamlarına gelmektedir. Teknik olarak, uygun davranışları teşvik eden, her türlü kabahat ve suçu önleyen devletin bir kurumunu ifade etmektedir. Hisbe teşkilatının, kadılık, mezalim mahkemesi ve şurta (toplum polisi) gibi İslami yargı müesseseleri ile yakın ilişkisi bulunmaktadır. Hisbe'nin fonksiyonları arasında kamu hukukunun korunması, düzenlenmesi ve pazardaki alıcı ve satıcıların davranışlarının denetlenmesi suretiyle bir anlamda sağlıklı ortamın oluşturulması bulunmaktadır. Hisbe esas olarak herkesin güvenliğinden emin olacağı şekilde hayatını sürdürebileceği, sosyal hayatın düzenli ve güvenli olduğu, tüketicilerin haklarının korunduğu ve toplumdaki ahlaki çürümenin önlendiği bir toplumsal düzen oluşturmak amacıyla İslami değerler ve ilkeler dikkate alınarak geliştirilmiş̧ bir mekanizmadır.

Gönüllü bir hesap-verebilirlik ve denetim sistemi olarak Hisbe'nin kökleri İslam'ın devlet olarak teşkilatlandığı ilk günlere kadar uzanır. Bu dönemde, Müslüman devletler pazarların kontrolü, yerel bazı hizmetlerin sunulması ve gerek toplumda ve gerekse ekonomide oluşabilecek bazı küçük sorunların kısa yoldan, etkili ve adil bir şekilde çözülmesini sağlamak amacıyla ayrı bir kurum teşkil edilmiş olup, bu kurum zamanla gelişerek işlevlerini artırmıştır. Tarih boyunca, zaman zaman önemi azalsa da, bu kurum farklı isimlerle ve farklı kurumsal yapılar halinde

\section{Abstract}

The word hisbah literally means "sum" or "reward." Technically, it connotes the state institution to promote the proper conducts and to avoid all types of misdeeds or offences. The institution of hisbah has been acknowledged as one of the main components of Islamic judicial institutions which has a link with various institutions, inter alia, qada', mazalim and also shurtah. The function of the hisbah, therefore, consists of maintaining public law and order and supervising the behavior of buyers and sellers in the market with a view to ensure the right conduct. The hisbah is basically a control mechanism established by Islam to maintain the order of social life, so as everyone will enjoy security and fulfillment of his or her basic needs. It is also meant as an instrument to safeguard society from deviance, to protect the faith and ensure the welfare of the society in both religious and worldly matters.

As a voluntary accountability and auditing system, hisbah has its roots in the early days of Islam when the Muslim states established a separate office to supervise markets, to provide municipal services and to settle petty disputes. Throughout history, this institution has existed in one form or another, and major functions of this institution has been performed nowadays by various public sector agencies and by local government units.

This article has two objectives: the first is to identify the position of Hisbah in Islamic public management, while

\footnotetext{
* Istanbul Medeniyet University, Faculty of Political Science, Turkey, ates.hamza@gmail.com
} 
sürekli var olmuștur. Günümüzde de, her ne kadar Hisbe kurumu geleneksel haliyle devam etmemekte ve tüm işlevlerini bir arada yerine getiren bir kuruluş bulunmamaktaysa da, bu kurumun önemli işlevleri değişik kamu kurumları ve yerel yönetimler tarafından yerine getirilmeye devam etmektedir.

Bu makalenin iki amacı vardır. Birincisi Hisbe kurumunun tarihi gelişimi, temel fonksiyonları ve bu kurumun meydana getirilme ve geliştirilmesinin ardında yatan nedenleri incelemek, ikincisi ise Müslüman ülkelerde bu kurumun fiili uygulama yöntemlerini incelemektir. Makale, Hisbe kurumunun tarihi gelişim sürecinin özetlenmesi ile başlamakta, Hisbe kurumunun başlıca işlevleri ile bu kurumun yöneticisi konumundaki "Muhtesib"in rolü ve görevlerinin kısa bir analizi ile devam etmekte ve bu kurumun işleyiş yönteminin Osmanlı, Pakistan ve Malezya örneklerinde incelenmesi ile son bulmaktadır.

Anahtar Kelimeler: Hisbe, Muhtesib, Adalet, hesapverilebilirlik, müşterinin korunması, Osmanlı, Malezya, Pakistan. the second being to adduce the philosophy and ethics behind the implementation of Hisbah. Therefore, the article examines the basic principles of the institution of hisbah, by primarily focusing on the structural ramification, operational barriers and complications in the mechanisms of institution of hisbah, as well as such issues as functions of hisbah in commercial sector and in consumer protection and the survival of hisbah in modern economic system. It particularly highlights the 'vague jurisdictional limitations', 'dynamics of the post of Muhtasib' and 'gaps between theory and practice' as leading effects that were experienced in continuous series throughout the history of this institution.

Keywords: Hisbah, Muhtesib, Justice, accountability, consumer protection, Ottoman, Malaysia, Pakistan.

\section{INTRODUCTION}

Perhaps one of the most arguable institutions of in muslim countries during the centuries is "Hisbah". Literally, "hisbah" is an arabic word derived from the root "h.s.b." and has a variety of meanings such as "calculation","verification", "reward" and "to take into consideration". According to Mukhtar (1987), the usage of the noun hisbah (in some countires ihtisab) came to be associated with the activities of a person who invites other people to commit good deeds (ma'ruf) and forbids them from evil activities (munkar) in the hope of getting a reward in the hereafter". From here, the term hisbah connotes the state institution to promote the proper conducts and to avoid all types of misdeeds or offences.

Hisbah institution is an Islamic position on the application of principles of Islam "enjoining what is good and forbidding what is bad", which is obligatory for any person who is in charge of public affairs to appoint some qualified people on that assignment. Although it is an individual obligation on the ruler to appoint an appropriate person on the post, it is also a collective obligation on others to make sure that 
the aim of enjoining what is good and forbidding what is bad is not defeated (Muhtar, 1987). Hisbah as a collective effort in assisting the Muslim community is based on as directed by Al-Quran, (5:2): "Help you one another in Al-birr and At-taqwa (virtue, righteousness and piety) but do not help one another in sin and transgression." (Attahiru el al.,2016).

This article assesses the role of Hisbah institution in ensuring ethical business practices for Muslim countries. The article argues that contrary to the notion many people have in the contemporary world, the institution of Hisbah could still be a convenient mean for not only serving spiritual and social purposes in the society lacking of economic contribution but also for the fact that it has specific role in ensuring that businesses are conducted in line with business ethics (Dograwa, 2011).

\section{HISTORICAL DEVELOPMENT PROCESS OF HISBAH INSTITUTION}

The religion of Islam predicts a type of human being who is responsible for his environment, encouraging goodness, and preventing evil. This duty was given by the Qur'an and Sunnah to all the individuals who constitute the Muslim community. A Quran verse is like this: "You are the best of peoples, evolved for mankind, enjoining what is right, forbidding what is wrong, and believing in Allah. If only the People of the Book had faith, it were best for them: among them are some who have faith, but most of them are perverted transgressors." [Al-Imran 3:101]. Prophet Muhammed also affirms this fact in the following way: "Whosoever among you sees an act of wrong should change it with his hands. If he is not able to do so, then he should change it with his tongue. If he is not able to do so, then with his heart, and this is the weakest of faith" [Bukhari and Muslim]. The Qur'an and the Sunnah have burdened all muslim individuals with the task of encouraging good and evading evil. Though the duty of encouraging good deeds and preventing evil ones is an individual obligation of muslims, throughout history, muslim states had perceived themselves as empowered to establish arrangements to oversee its implementation or at least coordination of individual efforts in this line. Hence, some institutions have been established in order that Allah's orders and prohibitions can 
be applied in daily life. For instance, zakat collection officers and zakat institutions have emerged in order for zakat to become widespread in society. In a similar vein, administrations of Islamic states established Hisbah agency whose duties are carried out by carefully selected people according to a clear set of conditions in order for its activities to be properly managed by the state, in order for the state to coordinate its efforts in discharging its responsibility of enjoining good and forbidding bad (Dogarawa, 2012)

The main mission and purpose of the Hisbah institution, since its outset in the early Islamic state in the Prophet's time, is to protect members of society from deviance, preserve their faith and guarantee the welfare of the people in both religious and worldly matters according to the Islamic and trafition-based law. Further, this institutions has served as a control mechanism to maintain the order of social life, so that everyone will enjoy security and the fulfillment basic needs (Al-Hamar, 1999; Abdullah, 2010, Dogarawa, 2011-2013). Development of Hisbah institution has had an evolutionary stage, in that, while Hisbah activities were mainly conducted through preaching and advising indivuals in order to encourage moral behavior and to discourage immoral ones at first, over time, the Hisbah activites went beyond religious preaching towards taking care of general social issues (Elsergany, 2010). While, after the Prophet, the first four caliphs personally performed this duty, in the later period when government affairs became complicated and multi faceted, a special officer was appointed to perform the duty of Hisbah, called muhtasib. In its maturation stages, this institution were enmpoered to deal with different social issues from maintenance of cleanliness of roads to animal welfare, from health care to preventing teachers from severe beating of children, from preventing alcohol and narcotics to became widespread to preveting furnication and adultery.

As the social tasks of Hisbah institution continued to grow over time, The Hisbah institution had become a key institution for Muslim societies under different names and diverging missions depending on the social needs and visions of statesmen in Muslim States, up to late last a few centuries. However, when Muslim states began to loose their strength since $18^{\text {th }}$ century and most of soverign muslim countries had become dependencies of Western powers under the 
colonialism trend, Hisbah institiuion suffered a drastic decline (Khan, 1999; Kahf, 2000). "Where it continued to exist, it further disintegrated into a number of departments and in some places remained an ineffective appendage of the state organs" (Dograwa, 2011). Many of its functions were reassigned to non-religious state departments or autonomous institutions in such Muslim lands of Ottoman Turkey, Iran and Egypt. An exception was the Saudi Arabia, where she disintegrated tasks and functions of Hisbah institution into two main groups and retained intact the religious wing of the Hisbah, while distributing its secular functions to different public organizations and ministries.

However, an ironic development is worth to mention here. A number of European states have adopted the Hisbah system when they witnessed its functioning style during the course of Crusades and when they develop close relations with Muslim countries such s the Ottoman State, while the importance of Hisbah was in decline in muslim countries. For instance, when European powers which came to the Middle East for Crusades occupied Jarusalem in 11 the and $12^{\text {th }}$ Centuries, they decided to retain the Hisbah system and allowed Hisbah officers to check markets and shops, to prevent fraud goods to be brought by vendors and peddlers to the market; and make sure that basic necessities such as bread and oil are always available in the market. Later, some functions of the Hisbah institution were transferred to the West gradually, under different names and formats. A well-known instition which was established through emulating some functions of Hisbah is the Office of Ombudsman.

Taking this general historical development background in mind, it would be useful to look into development of special features and functions of the Hisbah instititution. There is a huge literature on the development of Hisbah institution and its modes of operation throughout history. Particularly, its economic functions such as market regulation and consumer protection and justice-related functions such as protecting rights of individuals against state officials are more focused on. As justice is a major principle of Islam for governing the society, Muslim governments had sought to find ways to operationalize the principle of justice to make their citizens and subjects happy and to regulate the marketplace in order to prevent exploitation of the consumers by deceitful activities of fraudulent traders. As these functions 
are of importance by both the religion of Islam and well-functioning of state and society, religious scholars have produced a great volume of literature on Hisbah functions, in addition to the scholars who had intensively written on social issues and state affairs. Well-known early muslim scholars who contributed to Hisbah litareture included Al-Ghazali, Abu Yusuf, Ibn al-Qayyim, Muhammad al-Qurashi, Ibn Khaldun, Ibn Taymiyyah, ), alShaizari and Abu Ya'ala. As most of the literature above was mainly on the religious aspects of Hisbah, relatively recent writings on this issue are in general about its social, economic and justice-related dimensions. The latter includes Khan (1994, 1999, 2011, 2012), Islahi (1988, 1995, 1996, 1999 and 2005), Dograwa (2011, 2012), Kahf (2000), Al-Hamar (1999), Murtuza (2000) and Holland (1982).

Many of contemporary historians agreed that the term 'al-muhtasib' was used for the first time during the Abbasid caliph al-Mahdi. Throughout the evolution process of the office, the holders of the post of Hisbah appear to have been called with different titles such as "sahibu's-suk", "ihtisâb ağası", "muhtesib ağası" and "ihtisâb emini."

The Hisbah institution had continued to be a central institution during the history of Islamic rule, as it had been the core ingredient in the management and development the Islasmic nation, particularly during the Abbasid era. "During the Fatimiyyah period, the importance of the institution of hisbah has become more obvious in terms of enforcing the prescribed rules and regulations. In fact, muhtasib is not merely investigating business places and determining the proper weights and measurements but also ensuring that there must not be overloaded items being carried out by the traders. In addition, the scope of muhtasib's duties also has been extended due to the fact that they also are responsible in maintaining the morality of the subjects so that the members could live peacefully in the society. Later, enforcement officers' institutions like police force have been set up in order to impose upon, together with enforcing the prescribed penalties among the wrongdoers" (Md Shah, et al, 2015).

Over time, however, the prestige of the Hisbah institution was decreased, particularly when the government weakened during the early 10th/16th century in Mamluk reign of Egypt. The position of 
muhtasib was become obtained by payment of money and the office is held by those who lack the basic qualities of muhtasib. It was the Ottomans who restored the prestige of the Hisbah institution and increased its jurisdiction. In Ottoman administration, in addition to hisbah's conventional functions, Hisbah institution (ihtisab in Ottoman official resources) also empowered to deal with levying dues and taxes on traders and artisans.

Another contribution of the Ottomans to Hisbah institution was codifying functions and duties of the muhtasib through the ihtisab qanunnameleri, for the first time in Islamic history. Codification of Hisbah began under Sultan Bayazid II's (1481-1512) rule and continued under the rules of subsequent Sultans. "It may be noted that these regulations also included the original functions of muhtasib such as supervision of civil behaviour and morality in public and observation of religious rites. Muhtasib was also responsible to collect certain taxes.. The office of muhtasib or ihtisab ağası, as it was called, was farmed out annually (iltizam), and the holder used to receive a certificate of nomination after approval by the qadi, the Grand Wazir or the governor of the province. This was possible only after he had paid a certain sum called the bedel-i muqata ah [badal al-muqata 'ah in Arabic] or cash-value of the right to farm" (Islahi, 2005).

\section{ROLE AND FUNCTIONS OF MUKHTESIB}

One of the main aims of Islam on governing the affairs of state and society is to bring a stable and secure society filled with love, whereby the members of society work together in righteous activities. Therefore, Muslim jurists have put some principles to preserve the five universal needs of mankind i.e. faith, life, reason, lineage, and wealth. These principles also privde main raison d'etre of the hisbah institution, in that it has to function to ensure that this mission is properly carried out. Saleh (2009) lists the main goals of hisbah as follows:

a. Protecting religious values and encouraging religious-based deeds

b. Preparing a righteous society by supporting and cultivating high moral standards and by combating immoral behavior. 
c. Preparing the righteous believer to be concerned with the affairs of his society and to work for its welfare.

d. Providing the members of society with a constant monitoring of their activities, supporting and strengthening positive activities, while combating and preventing corrupt ones.

As Hisbah an important social/religious/economic institution, Islamic law has described a special procedure and determined some qualifications for the appointment to the post of Muhtasib. "The Muhtasib is to be a free Muslim male with a high degree of integrity, insight, reverence and social status. He is supposed to be a scholar of the state affairs, law and religion... with a high degree of in- depth knowledge in the social customs and moors. Of qualities of Muhtasib knowledge, kindness and patience are considered to be of prime importance. Hisba is an important institution. It can investigate matters which affect the morality of the public" (Khan, 2011).

As it performs quasi-judicial functions, although not forming a part of the judiciary, and embraces all aspects of life, whether worldly or religious, being an independent and impartial institution is a vital feature of Hisbah. Not only mukhtesib, but also any people which work for the Office of Hisbah need to carry some individual moral, social values and commercial dealings, as Hisbah is supposed to supervise the whole economic enterprise.

Some duties of Muhtesib, according to Islamic teachings, include (Khan, 2011):

1. To command the fulfillment of trusts;

2. To prohibit all evils and misdemeanor, particularly lying and dishonesty. His job is to make sure that there is no dishonesty with regard to weights and measures, manufactured goods, credit transactions and trade in general;

3. To keep a check on the practice of hoarding.

4. To prevent the instances of fraud in all sorts of transactions by laying down specific and detailed rules for different traders. 
6. To keep an eye on all trade and to make sure that those who work in a trade are well qualified for the job and know the rules of the law and regulations in respect with businesses.

7. To ensure that all the needs of people are taken care of.

8. To keep an eye on the conduct and honesty of those merchants who deal with lady customers.

9. To check business frauds and adopt policy for its eradication.

10. To take notice of other market imperfections such as the practice of intercepting of goods before they reach the market, in order to protect interest of the consumers and public at large.

\section{MAJOR FUNCTIONS OF HISBAH INSTITUTION}

As hitherto explained, the institution of Hisbah was developed over the centuries and its scope and functions of its chief (muhtasib) were step by step established. Further, Islamic societies from Malaysia to Saudi Arabia from Ottoman Turkey to Morocco varied in their structure and complexities, as muslim societies in different regions of the world has had to a some extent different kinds of problems. Hence, as even the society of a region or a country does not remain static, the establishment of Hisbah organization, functions and modus operandi of the institution as well as the steps taken by the hisbah officials are deemed to change. For instance, while in some countries the institution of Hisbah is preserved in its entirety to a great extent, in most cases tasks accomplished by the officials of the medieval Islamic state under the institution of hisbah have been reassigned to the judiciary and to the police organizations. Furthermore, traditional/ historical functions of Hisbah institution would have contemporary implications in both muslim and, surprisingly, non-muslim countries, as the functions performed by Hisbah officials have been real needs of the society, whether medieval or contemporary, and the economy of all kinds.

Traditional functions of Hisbah institution could be evaluated in three groups, namely;

a. market regulation and enhancement of ethical business 
b. mediating between state and society

c. preserving public interests through commanding (enforcing /advising) goods and forbidding the evil deeds and behaviours within the society

These functions can be translated into the contemporary world taking the tasks and functions the institution into account such as Ombudsman office, Community Policing, Market Regulator Agency, Religious Affairs Advisor, Social Worker and Law Enforcement officer.

It would be instructive to investigate some of its traditional functions briefly.

\section{a. Supervision of markets}

It was the leading area of hisbah. The earliest available writing in the form of a book (Ah\}kām al-Sūq ) o $\mathrm{n}$ the hisbah is by the third century Andalusian jurist Yahyā b. 'Umar Kinānī (/828-902 CE) clearly explored this function of Hisbah institution. The official which had worked on the name of Hisbah institution with the task of market supervision was named as sāhib al-sūq. His prime responsibility was to put standards in veights and measures used in markets and ensure the use of standard weights and measures. "He used to ensure that commodities were sold at approved prices and prohibited practices like sale of wine, indulgence in usury and gambling were not committed. He had to look after the interests of all those concerned in trade and business and to ensure no one was duped or illegally benefited. That is why, the hisbah manuals prepared from time to time included chapters on the malpractices used in manufacturing and sale of goods. Muhtasib was therefore considered to be a person equipped among other things with sufficient knowledge of trade rules and regulations. He was also entitled to appoint professional experts for his assistance to detect the malpractices in manufacturing of goods" (IPS, 2017: 1).

\section{b. Promotion of religious life and facilitating the practice of Islamic Worships}

In its early statges, a major responsibility of the Hisbah institution was to ensure that people were regular in offering five-times obligatory prayers at proper timings. However, the role of Hisbah was not only 
to encourage muslims to do their prayers, but also, and more importantly, to ensure maintenance of mosques, cleanliness around them and the appointment of mu'azzins. Some historians acknowledge that Hisbah officials have a significant role in such issues as observance of Friday congregational prayer and Eids (two annual religious festivals) and payment of zakāh by rich and wealthy people.

\section{c. Protecting public interests and the rights of weak segments of the society}

Another mission of Hisbah institution was to guard the public interest by and large. The institution had served public interest through fighting the malpractices of the market, like hoarding and corruption. The Hisbah institution and its chief, muhtesib, were responsible for protecting the rights of disadvantageous and relatively weaker segments of society (those who are handicapped, daily wage-earners and children etc.) against the excesses of the rich and powerful people. This role could be considered as an early version of social work In many cases, Hisbah was also empowered to deal with other social aid issues eighter individuallay providing social aid to poor or providing arbitration between rich and wealthy charitable people and poor and needy.

\section{d. Protoecting animal rights}

According to Islamic principles, humanity is not allowed to do everything to the living things and must only take their lives if necessary. Furthermore, there are Islamic restrictions on manipulating animals, such as limited hours of work. Similarly, hunting of young birds for pleasure is forbidden by Islam. From the Islamic viewpoint, animals represent Allah's might and wisdom, and humanity must pay attention to their health, feed and living conditions. Islam determines the living costs of animals and orders humanity to respect and not to abuse them. Therefore, Hisbah officials were empowered to protect animal rights and to ensure betterment of living conditions of both dometic and wild animals as well as to warn those who committed cruelty to animals. 


\section{e. Community policing activities}

Traditionally, a chief mission of Hisbah institution has been certain type of community policing, in order to contribute to moral development of the society. However, Hisbah officials are not police officers themselves. Although there is a strong relationship between police and Hisbah organizations, the relationship here is complementary, in that Hisbah produces and presents to other authorities mainly preventive measures to be taken against the acts which disrupt order and morale of the society such as violence, crimes against women and child abuse. The Hisbah officers have to constantly be in contact with local judges, police authority, local branches of the central government, local government, civil society organizations and other branches of administration in order to prevent crimes and bad behaviors in both market and society.

Although Hisbah institution has also power render necessary assistance to the police and other secuirity agencies especially in the areas of deterrence, revealing and reporting of crimes in such shariah-implementing countries as Saudi Arabia and some states of Nigeria and Indonesia, (Garba, 2017; Feener, 2012; Hakeen et al. 2012), "islamicness" of this practive is still debated (Garba, 2017). "The discussion on how the Office of Hisbah is expected to discharge its duties particularly in the area of forbidden evil is quite - reflective of the inherent gentility, fairness, politeness and wisdom... By this, it can safely be stated that, the characteristics of the concept of community policing are inherent in the Islamic Institution of Hisbah in the area of performing their functions" (Garba, 2017). For instance, the Bauchi State's (in Nigeria) "Guidelines On The Formation, Functions And Operations Of Hisbah Committees in Bauchi State" contains a provision on community policing in the functions of Hisbah, through item 2.0: "Uniting people of a particular community to solve their common problems related to moral issues, social welfare, youths unemployment, etc. so as to complement government activity" (paragraph 2.1.3) and "Resolution of conflicts and making peace between individuals, groups, and communities without having to resort to courts" (paragraph 2.1.2). This envisages partnering with the community in solving problems of fighting the evil through cooperation as advocated by community policing philosophy (Garba, 2017). 


\section{f. Protecting customers}

Another key mission of Hisba is to protect interests of the consumers on behalf of the state. In order to ensure consumer protection, Hisbah institution were geneally empowered to produce some regulations and to encourage traders to take care of the interests of the consumers. Muslim scholar Ibn al -ukhuwwa says (in Khan's (2011) quotation): "Traders must not set out seats or benches beyond the line of pillars supporting the roof of the Suq so as to obstruct the way for passers-by. The prolongation of party-walls (porches) and side buildings and the planting of trees are forbidden, the ways (through the Suq) being common property through which the public has the right to pass. So also the tethering of animals is forbidden except as required for alighting and mounting. Sweeping refuse into the passage-way, scattering melonskins and sprinkling water which may cause slipperiness there are all forbidden. Water-spouts may not be allowed to project from walls so as to cause defilement of the clothes of passers-by and obstruct the streets. Rain-water and mud must be swept away from the streets and it is the duty of the Muhtasib to appoint persons to have care of such matters. He must also prevent the carriage through the Suqs of loads of wood, bales of straw, water-skins, baskets of dung, etc., reeds or thornbushes which may do damage to the clothes of the public and which must go by wider streets if these are available. If not, then as public necessities they must be permitted to pass. Heavy loads must be removed from the backs of the pack- animals standing in courtyards, in order to prevent cruelty and is the Muhtasib's duty to order this to be done. He must see to it, further, that the occupants of Suqs maintain them in cleanliness".

As Khan (2011) asserts, it is a task of Hisba officials to interfere in trade and business activities in order to protect consumer rights and interests. In short, "the institution of Hisba is fully authorized to take cognizance in any type of commercial activity when it violates basic rights of the consumers and public at large. The institution of Hisba is responsible for the regulation of business and economic life of the people" (Khan, 2011). Consumer protection activites of Hisbah would include checking quality of products, inhibiting hoarding, controlling official mint and implementing a number of preventive measures to decrease malpractices in trade. 


\section{g. Promoting Ethics codes to business and preventing unethical behaviours in economic activities and within society}

Hisbah institution also controls the unethical behaviors in economic affairs through the prevention of fraud in the industries and markets with more emphasis on the supervision of weight and measures (Elsergany, 2010). An enforcement institution like Hisbah institution is deemed necessary to promote ethics within the society and in the business transactions, because of the variation of people in their extent of righteousness motivations ((Salim et al., 2015).). In other words, the motivation behind establishment of such an institution was the common belief that naturally and habitually, people are inclined to commit bad behaviors and become submissive to evil desires. Hence, good laws, practice and policies as well as efficient utilization of rulers with a good record to discourage the people from committing unethical behaviors is needed. However, it is generally accepted that transparency and fairness in the business transactions would not be safeguarded only by the knowledge of ethical knowledge, and similarly, producing regulations are not enough to enforce ethics without moral obligations and enforcement, consequently a synergy between them should be proven if the intended objective is to be realized (Dogarawa, 2011).

\section{h. Other economic roles}

In the classical age of Islam, economic roles of Hisbah officials extended to a wide-ranging area from monitoring of artisans and craftsmen such as bakers, butchers and restaurants, supervising commercial markets and reporting misdeeds in business activities to state authorities. Regarding the freelance such professionals as , engineers, physicians, chemists, lawyers and teachers, Hisbah authority make sure that they exercise their vocations not only in a manner that it would provide profit maximization, but also to bring benefit to the society.

Although mission of Hisbah was not compulsory in some task areas, economic roles were generally taken seriously. "Remarkably, the Hisbah officer was being assisted by boys and girls to help him detect fraudulent merchants; warn him for the first time, and if the merchant eventually repeats the unethical market practice and does not repent 
after beating and defamation in the market; he may be exiled from the country" (Dograwa, 2011: 6-7).

In order to perform its task efficiently, Hisbah institution need to have a large organization nationwide, and show presence in almost every sector of human life principally in the field of commerce and its activities should include a wide-range from investigations, supervision and regulation to holding, capture, confiscation, and destruction of substandard, fake and polluted goods. Moreover, Hisbah institution should have skilled, trustworthy, reliable and competent members who represent the Hisbah authority in various professions. Such Hisbah officials need to familiarise themselves with the trades, activities and crafts they are involved in (Barkindo, 2011, Dograwa, 2011).

\section{MODUS OPERANDI OF HISBAH INSTITUTION: COMPARING THE OTTOMAN, PAKISTANI AND MALAYSIAN CASES}

\subsection{The Ottoman System}

Muslim-Turkish states from the Saljukis onward preferred to use ihtisâb in administrative sense, while the word hisbah was reserved for the virtue and principle (Inalcik , 1990; Kaya, 2006). The Ottoman muhtesib, usually called ihtisâb ağası, was responsible in principle for "seeing to it that Muslims in the city followed the precepts of the Shari'a and lived a thoroughly Muslim life." In reality, however, he was responsible for the good behaviors of the people in the marketplace. He used to be appointed by the judge, together with senior officials of his office. Muhtesib acted as a subordinate to the judge with respect to the affairs of markets, with particular authorities and responsibilities. A chief difference between the judge and the muhtesib was its power of judgment of the offenders. While, in matters requiring evidence and jurisdiction, the muhtesib had no authority but informing thejudge; In apparent matters requiring no evidence, the muhtesib could act on his own, if the matter falls into his responsibility.

In Ottoman practice, ihtisâb was more closely related with the market than in the classical sense. The government promulgated ihtisâb regulations, which featured the characteristics of hisbah. However, 
these regulations contained articles mostly concerned with the professional ethics of the guildsmen.

The ihtisâb codes (kanunname), dating from the early sixteenth century, regulated the operation and production of different trades, and determined the duty of the ihtisâb ağası. The code of Istanbul dated 1501 served various functions such as, fixing the prices, regulating the provisions for the city population, describing the proper process of production for various trades, establishing covenants of guarantee for the products, regulating the distribution of raw materials, banning the malpractices among the esnaf and the men of muhtesib and inspecting the prices, as well as the classical hisbah practices.

Firstly, it appears that muhtesib was subordinated to the judge (kadi) in many actions, along the same lines with the classical Islamic states. Other than the organization of the guilds, the concern to protect the rights of God and the rights of men is apparent. "Muhtesib was ordered to inspect the usurers and punish them if they lent money at a rate more than 20 percent. He would punish the perjurers with the affirmation of the kadi. He was to draw the lepers out of the city and supervise the work of the physicians, the druggists, and the surgeons. Besides these, he had to see to it that the Muslims observed their prayers and fasts in Ramazan by asking the imams of the mahalles" (Kaya, 2006).

There is a consensus in the historiography as to the socio-political origins of the persons assigned to the post of muhtesib of Istanbul. It seems that the holders of this post were generally among the ranks of the soldiers which are educated in the Palace administrative school, called Enderun). The field organization of the office of muhtesib in provinces, too, was almost a mini copy od the centre. Ihtisâb (hisbah) services in the provinces were entrusted to the sons or relatives of servants in the imperial palace.

Altthough newly established Republic of Turkey officially replaced the Ottoman State, many of administrative and political organizations and their modus of operandi were inherited from the Ottoman State. Therefore, Turkey is generally considered as a continuum of the Ottoman State in terms of public administration. Although the prestige of Hishah institution was lessened and the functions of Hisbah 
were distributed to other both secular and religious organizations as well as to some civil society organizations towards the end of the Ottoman State since the $18^{\text {th }}$ Century, individual functions of Hisbah survived to some extent in one way or another. For instance, dealing with construction and cleanliness of the mosques has become responsibility of the Agency of Religious Affairs, social aid activities survived by foundations (waqfs) and the Ministry of Social Policy, community policing function has been performed by the Polic Authority (although with a secular In addition content), prime responsibility is rested upon Ministry of Trade and regulation of the economic activities is done by independent administrative authorities. In addition to penal code, the Turkish government enacted Law of Misdemeanors (Kabahatler Kanunu) in 2005 to protect social order, environment, social morale and economic order. The last initiative in this line has been establishment of the Office of Ombudsman in 2013. However, as Turkey is a constitutionally secular state, most of the contemporary versions of the functions of Hisbah institution have been isolated from their religious nature and gained secular content.

\subsection{The Malaysian Experience with Hisbah}

Islam was once the law of the land in Malay land throughout centuries before the colonial period. After ndependence, Islamic principles and institutions have been regarded as the only way to unite the Muslims and to maintain traditional values. "It was also argued that the institutions of hisbah would bring out the beauty of Islam so that Muslims and non Muslims alike look at Islam as the religion of humanity which brings peace to the community" (Muhammad, 2016). As Malaysia is a federal state, most of public services are provided by each autonomous region, rather that the federal state. Therefore, each autonomous region has its own department in preventing immoral activities, under different names, while the nature of the work are the same i.e., to curb activities contrary to codes of ethics and law. The Syari'ah Criminal Offences Enactment listed the immoral activities to be prohibited or at least discouraged which can be categorised in four categories: sanctity of the religion of Islam and its institutions, 'aqidah, indecency and miscellaneous behabiors and deeds. 
In Malaysia, theere are a number of institutions which carry out similar roles of Hisbah, including Jabatan Kemajuan Islam Malaysia (JAKIM) and Majlis Mufti Kebangsaan as well as religious institutions at the state level such as Jabatan Agama Islam (JAIS), Majlis Agama Islam Negeri Sembilan (MAINS) and Majlis Agama Islam Pahang (MAIP) In Selangor. A particular institution which woth mentioning in terms of Hisbah activities is the Enforcement Division of the Department of Religious Affairs whose prime responsibility is to take care of any immoral activities of muslims and whose chief is regarded as muhtesib (W. Muhammad, 2015: 34). However, its mandates are quite limited, in that religious enforcement officers neither can arrest the wrongdoers nor charge them in the courts; rather they can only warn them.

The mandates given to the Religious Enforcement Officers in exercising the functions are basically governed by the constitutional law. For example, the Syariah Criminal Procedures Act (1997) empowers Religious Enforcement Officers to arrest the person by reasonably and physically touching the body of that person either under warrant or without warrant. In addition, Religious Enforcement Officers can search the place entered by the person sought to be arrested with or without warrant, and can seize articles that are believed to have been used in committing the Syariah offence. Among other functions of the Religious Enforcement Division are "to receive information of the immoral activities committed in the society either in public or private and accordingly take actions in accordance with the laid down procedures, to implement or enforce the law related to Syariah criminal offences, as well as to investigate the cases related to such offences before the arrested person can be prosecuted by the Syariah Prosecutor" (Muhammad, 2016). In addition to the above, each state has its own religious affairs departments. The names of these departments differ but they perform more or less similar functions.

As seen, Malaysia has preferred to implement community and moral policing functions of Hisba institutions, alongside market regulation, customer protection and other economic functions which the latter are not come into fore visibly in comparison with community policing and protection of Islamic values functions. 


\subsection{The Pakistani Experience with Hisbah}

A successful case of Hisbah institution was seen in the classical age of Islam in the Indian subcontinent. According to Umar b. Muhammad al-Sunāmī, a 14th century muhttasib of Tughlaq dynasty (1320 to 1413 C.E.), major functions of Hisbah institution of the time included fighting with bid'ahs ([innovations in Muslim beliefs and practices that were not sanctioned by the Qur'ān and the Sunnah), advising the society in direction $\mathrm{f}$ Islamic teachings, leading in daily prayers and Friday Pray, dealing with such social affairs of the community as funerals and marriages, warning the society against such bad habit of gambling and consumption of wine. As can be seen mainly religious functions were foremost in the Medieval Indian Hisbah experience. Hisbah, like many other traditional Muslim institutions, had lost its prestige and importance under the colonial rule beginning in $18^{\text {th }}$ century.

The colonial rule ended in 1947 with the emergence of India and Pakistan as two independent states. Pakistan, a separate homeland for Muslims, came into being with sheer commitment of the subcontinent Muslims to shape their lives in accordance with Islam. Although, in general, as the journey towards the transformation of Pakistan into Islamic state was concerned, it did not go beyond the constitutional declarations so far; establishement of some Islamic-oriented institutions such as Hisbah has been realised.

Establishment of the institution of hisbah has had an evolution process in Pakistan. Firstly, the military regime established the office of the ombudsman in 1983. Although the Office of Ombudsman was called "the Wifāqī Muhtasib", it fell short of the traditional concept of Hisbah. The main task of the Wifāqi Muhtasib is to repair the extravagances of the government officials against the public, due to interpretation of rules and regulations. Ombudsman performed only a few functions of the traditional Hisbah institution, excluding purely religious matters and moral advices to the society, as Ombudsman in Pakistan was established in line with Western institutions, rather than Islamc requirements.

A promising effort at establishing an institution wich is expected to function similar to medieval Hisbah came from MMA (Muttahidah 
Majlis-i-Amal) formed the provincial government in North West Frontier Province, (NWFP) one of the provinces of Pakistan in 2002. MMA prepared a draft Hisbah Bill in order to prevent the deteriorating Islamic social norms and encroachment of liberal values in society. The sections 9 and 23 of the draft of the Bill envisaged the responsibilities and mandates of the proposed Hisbah institution and its officials. These were:

- To execute adherence to moral values of Islam at public places;

- To discourage exhibition of extravagance particularly at the time of weddings and other family functions;

- To follow Islamic norms in giving dowry;

- To discourage beggary;

- To execute adherence to Islamic norms and to comply with respect and regard of Islamic values at the time of iftār and trāwīh;

- To discourage entertainment shows and business transactions at the time of Eids and Friday congregational Prayers around mosques where such Prayers are being performed;

- To remove the causes of laxity in performance and proper administration of Eids and Friday congregational Prayers;

- To discourage child labour;

- To remove unnecessary delay in discharge of civil liability that is not disputed between the parties;

- To prevent cruelty to animals;

- To remove causes of negligence in maintenance of mosques;

- To execute observance of Islamic norms at the time of Āzān;

- To prevent speeches meant to create hatred among sects and misuse of loud-speakers,

- To discourage un-Islamic social etiquettes;

- To check the tendency of indecent behaviour at public places,

- To prevent dissoluteness; 
- To eradicate the practices of tawìdh-selling, palmistry and magic;

- To protect the rights of minorities, particularly with regard to the sanctity of places and sites where they perform ceremonies of religious nature;

- To eliminate un-Islamic practices, that negatively affect the rights of women, particularly to take measures against their murder in the name of honour, to remove the tendency of depriving them of their right of inheritance, to eliminate the practice of Swara and to ensure their rights guaranteed by law;

- To execute standard weights and measures and to eliminate adulteration;

- To have check on artificial price hike;

- To protect government properties;

- To eliminate bribery from government offices;

- To instil feelings of service to people at large amongst government functionaries;

- To admonish those who are disobedient to their parents;

- To perform any other function or functions that the Provincial Muhtasib determines from time to time in consultation with the Advisory Council;

- To provide justice to the affected party in undisputed fiscal matters;

- To mediate amongst parties and tribes in matters pertaining to murder, attempt to murder and such other crimes threatening the law and order situation.

Although the MMA provincial government started the enactment process of Hisbah Bill in 2005, because of lacking in the constitutional approval of the NWFP governor, it could not become an act of the legal code so far. 


\section{CONCLUSION}

Hisbah is basically a control mechanism established by Islam to maintain the order of social life, so as everyone will enjoy security and fulfillment of his or her basic needs. It is also an instrument to safeguard society from deviance, to protect the faith and ensure the welfare of the people in both religious and worldly matters It is an institution developed by the Muslims to assist in regulating the society and economy and ensuring the full flowering of the Islamic norms of behavior. Although Hisbah institution was established long time before as a religious institution, the concept and philosophy being rooted in it is duly relevant to be applied within the realm of contemporary situation.

Saleh (2009) explains the reason of establishing such an institution according to Islamic teachings, using the following words: "According to Islamic tenets, all people should maintain truthfulness and avoid lying, especially when they deal with the business enterprises and economic interests. Since human beings are prone to neglect the necessity of truthfulness and are frequently tempted to engage in misdeed or fraudulence, there should be an institution authorized by the state that serves as a mechanism to help people keep their truthfulness and avoid all types of misbehavior. This is because people need order in their lives and, consequently, they are in need of some authority to ensure that order. Because of that, there must be someone to remind people of this order and to keep tabs on how well they are adhering to it. This is why enjoining good and forbidding evil is so instrumental in Islam".

In its heyday, Hisbah was a good-working institution which contributed to regulation of markets, filling the gap between state officials and citizens, providing justice, setting ethical standards for business and monitoring them and removing bad deeds and fraud from markets, society and state institutions. This is why this institution was emulated by western societies in a form or another. However, when muslim states become weaker and social/political decay began to grow, this institution was marginalized, its functions were disintegrated and assigned to different organizations and ministries and the overall function of Hisbah had become neglected. 
Although it started as a strictly religious institution aiming to put the Islamic principle of "commanding good and forbidding evil" into practice, the institution of hisbah has lost its religious dimension to a great extent and gained new features and is assigned new tasks which are mainly social, economic and human right promotion related. Certain aspects of hisbah are still maintained in form of assigning some of its functions to government departments and ministries in a number of countires, whether muslim or non-muslim.

Today, almost nobody doubts or denies the need a special institution, like Hisbah, with the task of ensuring justice, issuing regulations to make markets better functioned and to serve as an arbitrator between the sate and its citizens. As basic functions and missions of such an organization still survives, there is no reason for not astablishing a contemporary version of Hisbah instition, taking current social, administrative, political and economic needs and requirements into account. At present, many of the functions and roles of Hisbah institution are carried out in many countires within different organizations. For instance, the roles and duties of muhtasib and ombudsman are resembled to a great extent, these enforcement officers share the basic function, that is, to uphold justice for the benefit of the people entirely.

Similarly, contemporary economy remains acquainted of the necessity of control and supervision in governing business transactions. Within the absence of a comprehensive institution like Hisbah, some particular institutions are established more or less as a means to control some violations that may occur in dealing with the business enterprises that cause unfairness and lead to injustice. For instance, the main objectives of Competition and Antitrust Laws in liberal countries are protecting the interests of consumers and ensuring that entrepreneurs have an opportunity to compete in the market economy. In many countries, whether muslim or non-muslim, there are still some other institutions bearing equivalent functions of the hisbah. They have a great responsibility to enhance truthfulness and justice in economic dealing established by the government. They are equipped with the task of supervising and controlling any economic misbehavior which may cause great public losses and deficiencies. However, it is a matte of debate whether these institutions, representing the hisbah 
functions, could efficiently play their role in stimulating fairness and justice in business enterprises for a better future of the whole people.

Here, the religious and social tasks are inter-related, as the principles of Justice and social order are also main goals of an Islamic government. Further, principles of religion and social life, to a great extent, concides, particlularly a religioun like Islam which provides a large number of wordly principles and institutions to apply these principles is taken into account. For instance, the act of "commanding good and forbidding evil" reduces malpractices and ensures justice to all, irrespective of people's status, and contributes to maintenance of justice in its highest standards. 


\section{REFERENCES}

ABDUlLAH, A. (2010), "Harking back to Hisbah", Accountants Today, 12-14, www.mia.org.my/at/at/2010/04/04.pdf

AL-HAMAR, A. (1999), Enhancing Ethics in Private Sector through Hisbah, last retrieved in August 2008 from http://www.almuntada.org.jo/ english/islamprep.htm

AL-MAWARDI, A.H. (1966), Al-Ahkam as-Sultaniyyah: The Laws of Islamic Governance, London: Ta-Ha Publishers.

ATTAHIRU, Mustapha Sidi, Al-Hasan Al-Aidaros and Syarifah Binti Md Yusof (2016), "Moderating Role of Hisbah Institution on the Relationship of Religiosity and Islamic Culture to Islamic Work Ethics in Nigeria", International Review of Management and Marketing, 6(S8) 125-132

BARKINDO, I. (2011), The Role of the Institution of Hisbah in the Sharia Implementing States in Northern Nigeria, LLM Thesis submitted to the Postgraduate School, Ahmadu Bello University, Zaria, Nigeria.

COOK, Michael (2003), Commanding Right And Forbidding Wrong In Islamic Thought, Cambridge: Cambridge University Press.

DOGARAWA, Ahmad Bello (2011), "Role Of Hisbah (Ombudsmanship) Institution In Ensuring Ethical Business Practices: Reflection For Shari'ah Implementing States In Nigeria", Paper Presented At The 2011 Ben-Africa Conference Zanzibar, Tanzania 31 October - 2 November 2011

DOGARAWA, A.B. (2013), "Hisbah and the promotion of ethical business practices: A reflection for the shariah implementing states in Nigeria", International Journal of Islamic and Middle Eastern Finance and Management, 6(1), 51-63. Available from: http://www.doi. org/10.1108/17538391111144515.

ELSERGANY, R. (2010), "Hisbah in the Islamic administration system", Islamic story, Available from: http://www.islamstory.com/en/node/27466.

FEENER, R. M. (2012), "Social Engineering through Sharia: Islamic Law and State-Directed Da'wa in Contemporary Aceh". Islamic Law and Society 19 (2012), pp. 275-311. 
GARBA, Ahmed S. (2017), The Place Of Community Policing Under The Sharia'h And The Advent Of Hisbah, http://www.gamji.com/article6000/ news6178.htm (visited at 21.03.2017).

GHIBIN, Ahmad (2011), The Role of the Muslim Institutions in Architectural Activity in Medieval Islam: The Case of Hisba and Muhtasib, www.qsm.ac.il/arblanguage/docs/majalla/5/ahmad_ghibin_e.pdf.

HAKEEM, F. B., M. R. Haberfeld \& A. Verma (2012), Policing Muslim Communities: Comparative International Context, New York: Springer.

IBN KHALDUN (2012). The Muqaddimah. Trans by Franz Rosenthal. https:asadullaahali. Files. Wordpress.com/2012/10/ibn_khaldunal_muqaddimah. pdf. Ibn Manzur Jamal al-Din

IBN TAYMIYAH (1992), Public Duties in Islam: The Institution of Hisbah, trans. Muhtar Holland. Leicester: The Islamic Foundation, 1992.

IBRAHIM, Azrin (2015), “Accountability (Hisbah) in Islamic Management: The Philosophy and Ethics behind its Implementation", International Journal of Humanities and Social Science, Vol. 5, No. 8; August 2015

IBRAHIM, Azrin (2016), "Hisbah And The Sustainability Of Islamic-Based Development Institutions: An Observation” , International Journal of Science Commerce and Humanities Volume No 4 No 4 November2016

INALCIK, Halil (1990), “Istanbul: An Islamic City”, Journal of Islamic Studies 1 (1990) pp 1-23

IPS (2017), "Institiution of Hisbah and The Demand for its Revival", Institute of Policy Studies of Pakistan, http://www.ips.org.pk/politics/1185-the-institution-of-hisbah-and-demand-for-its-revival, (on 08.07.2017)

ISLAHI, A. A. (2005), Contributions of Muslim Scholars to the History of Economic Thought and Analysis, Scientific Publishing Centre, KAAU, Jeddah.

http://islamicus.org/hisbah/ (retrieved on 22. 04.2017).

KAYA, Mustafa İsmail (2006), Shops and Shopkeepers in the Istanbul İhtisâb Register OF 1092/1681, A Master's Thesis, The Department Of History, Bilkent University Ankara. 
KAHF, M. (2000), "Principles, Objectives and Tools of Market Regulation in Islamic Perspective", Paper Presented at a Seminar on Islamic Approach to Market Regulation and Economic Stability, Tehran, Iran. Retrieved on July 25, 2007 from http://www.monzer.kahf.com/papers/english/market_regulation.pdf

KHAN, Muhammad Akbar (1994), An Introduction to Islamic Economics, 1st ed. Pakistan: Intermational Institutue of Islamic Thought and Institute of Policy Studies.

KHAN, Muhammad Akbar (1999), “Al-Hisbah and the Islamic Economy”, published as Appendix in Ibn Taymiya, Public Duties in Islam: The Institution of Hisbah translated by Mukhtar Holland, The Islamic Foundation, Leicester, UK.

KHAN, Muhammed Akbar (2011), “The Role of Islamic State in Consumer Protection" Pakistan Journal of Islamic Research, Vol 8.

KHAN, Muhammad Akbar (2012), “The Institution of Hisba (Ombudsman) and Consumer Protection" Hamdard Islamicus, Jul-Sep2012, Vol. 35 Issue 3, p57-87.

MD SHAH, Mohd Ab Malek bin, Mohd Harun bin Shahudin, Sulaiman bin Mahzan Rani Diana Othman, Jeniwaty Mohd Jody (2015), "The Institution of Hisbah: In the Purview of Its Significances and Development", Global Journal of Business and Social Science Review GJBSSR, Vol. 1 (2), January-March, pp. 386-394

MUHAMMAD, Ramizah wan (2016), "Hisbah in Malaysia: Preventing vices and immoralities", International Journal of Islamic Thoughts, 5 (2). pp. $35-53$

MUHTAR, H. (1987), Public Duties in Islam. 2nd ed. Leicester, United Kingdom: The Islamic Foundation, Markfield Dawah Centre

MURTUZA, A. (2000), "Hisbah: the Islamic Variation for the Regulation of Marketplace and Commerce", paper presented at 6th Interdisciplinary Perspectives on Accounting Conference, Manchester, UK.

SALEH, Fauzan (2009), "The Institution of hisbah: Its Roles in Nurturing Fair And Just Economic System in Islam", Seminar Ekonomi Islam 
Peringkat Kebangsaan (SEIPK '09) "Ke Arah Pengukuhan Dan Pemahaman Aplıkası Sistem Ekonomı Islam Dı Malaysıa"

SALIM, Ssuna, Syahrul Faizaz Binti Abdullah, Kamarudin bin Ahmad (2015), "Wilayat Al-Hisba; A Means to Achieve Justice and Maintain High Ethical Standards in Societies", Mediterranean Journal of Social Sciences, Vol 6 No 4 S2 July. 